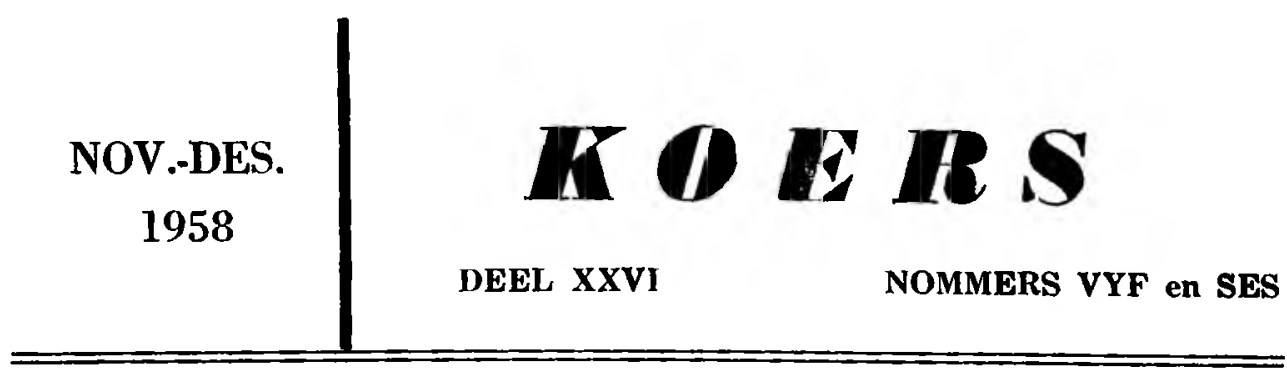

\title{
DIE TAAK VAN DIE BIBLIOTEKARIS IN ONS VERWARDE TYD
}

Ek staan vandag voor $u$ in diepe erkentlikheid. Sover ek weet is dit die eerste keer dat een van ons universiteite hierdie hoë eer aan 'n lid van die biblioteekprofessie laat toekom om by 'n geleentheid soos hierdie op te tree. Namens daardie professie aanvaar ek hierdie eer met ons innige dank teenoor $u$, meneer die Rektor, en teenoor $u$ Senaat. In my persoonlike hoedanig. heid wil ek u van harte bedank vir hierdie hoë. eer my aangedoen veral terwyl ek my tekortkominge om hier voor $u$ te verskyn ten volle besef.

Ek vra $u$ aandag vir 'n paar opmerkinge oor die intellektuele verwarring en isolasie van ons tyd en, na aanleiding daarvan, 'n kort credo van die moderne bibliotekaris.

Taamlik algemeen word daar vandag beweer dat die biblioteek in die moderne samelewing een groot taak het om te vervul, nl. wat die Amerikaners noem "the dissemination of ideas". Verder verwys ons graag na die biblioteek as die sinnebeeld van ons demokratiese lewenswyse, omdat die biblioteek gebore is uit die Westerse kultuur; omdat die individu in die biblioteek aan homself oorgelaat word vir die seleksie van sy intellektuele voedsel; omdat ons met die biblioteek gewoonlik assosieer die geleenthede wat daar in 'n demokratiese gemeenskap aan die individu verleen word om te kom tot sy hoogs moontlike intellektuele ontplooiing; en omdat ons in die biblioteek die produkte bewaar van die geestelike en intellektuele wors teling van die groot geeste deur die eeue in daardie proses wat ons maar kan noem die ,soeke na die waarheid". 'n Paar groot biblioteke in die wêreld is daar ook nog wel waarna verwys kan word as "skatkamers van die menslike kennis", maar in die algemeen kan ons na die moderne biblioteek verwys as die inrigting wat daarna strewe om vir 'n bepaalde groep mense ' $n$ bepaalde hoeveelheid materiaal aan te skaf, te orden en beskikbaar te stel met ' $n$ bepaalde doel. Die aard en omvang van die inrigting word gewoonlik aan bande gelê deur fisiese faktore soos die beskikbare fondse (wat nooit genoeg is nie), die intellektuele peil van die gemeenskap (wat altyd maar as te laag bestempel word) en die vermoë van die die bibliotekaris waar die gees gewoon- 
lik gewillig maar die vlees helaas seer swak is). Kortweg sou ons na die hedendaagse biblioteek kon verwys as 'n kommunikasiesentrum waar bepaalde produkte van die gees versamel, georden en beskikbaar gestel word. En dis in die vertolking en uitlewing van hierdie uitdrukking ,bepaalde produkte van die gees" - in die bepaling van hierdie woord „bepaalde”, dat die vernaamste probleem - ek wil byna sê die katastrofe - van die moderne biblioteek opgesluit lê.

Tot hede toe word as die belangrikste uitvindings van die mens beskou die wiel en die drukkuns. (Ons sal dit aan die oordeel van die komende geslagte moet oorlaat of hulle die splitsing van dit atoom as 'n derde hieraan wil toevoeg). Deur die uitvinding en die ontwikkeling van die drukkuns het die mens ' $n$ magtige middel gevind vir die verspreiding van sy idees in ' $n$ voorheen ongekende wye kring. Hierdeur het die kennis en die opvoeding deurgedring tot die breër volkslae, en op sy beurt weer het die opvoeding van die massas aanleiding gegee tot 'n stortvloed van bydraes of pogings tot bydraes tot die wêreldliteratuur - goed, sleg en middelmatig. Die kreet van ,kennis is mag" het in belangrikheid toegeneem, en geleidelik het die toestand ontstaan waarin die liggelowige met 'n goeie geheue deurgaan as ' $n$ beter mens as die kritiese denker, omdat hy meer onthou as laasgenoemde. Inderdaad het 'n woeste kringloop ontstaan sodat die moderne mens, met dieselfde menslike beperkinge as sy voorgeslagte, dermate toegegooi word onder die idees en gedagtes van sy tydgenote, dat daar nóg van historiese perspektief nóg van behoorlike assimilasie sprake kan wees. Die drukkuns wat ontstaan het as 'n magtige middel vir die opvoeding en inligting van die mens het ontwikkel in 'n magtige middel tot sy beïnvloeding en tot sy indoktrinasie. In die moderne wêreld is daar soveel duisende wie se idees en gedagtes in druk verskyn dat almal wedywer om hul eie publikasies in wydste kring te laat sirkuleer. En nou weet ons dat dit die skril stemme is wat in 'n kerkbasaar bò die geselsende menigte uitstyg.

Die drukkuns het twee belangrike beperkinge van die gesproke woord uit die weg geruim: 'n Spreker kan sy gedagtes slegs oordra aan 'n beperkte groep mense wat fisies binne hoorafstand van hom is. Die skrywer van 'n gedrukte stuk hoef nie meer by ons te wees nie. Waar sy taal verstaan word kan sy werk binne die leser se eie omgewing en tyd gelees word. Die skrywer hoef nie aan sy gehoor voorgestel te word voordat hy aan hulle sê „kom luister na my wysheid" nie. En nou vereis dit baie min praktiese mensekennis om te besef dat hierdie dinamiese gebruik van die drukkuns spoedig deur die handelaar aangewend sal word om aan die wêreld te sê ,kom koop my ware". En daar het $u$ in breë trekke die predikament van die moderne bibliotekaris: Hy staan voor die magtige stroom van die wêreldpers en daaruit moet hy selekteer en paraat stel wat nuttig en bevorderlik sal wees vir die gemeenskap wat hy moet dien.

Maar daar het $\mathrm{u}$ ook die predikament van die moderne mens: Tydig en ontydig word daar van owerheidsweë aan hom 
gesê: „Jy is 'n vrye, verantwoordelike, volwasse wese wat jou eie heil uitwerk. Aan jou opvoedingsgeleenthede word geen perke gestel nie, sodat jou volle potensialiteite kan ontplooi en jy jou bydrae kan lewer tot die geestelike inhoud van die tyd waarin jy lewe". Maar wat gebeur? Kom ons neem 'n kykie van wat daar met die gewone man gebeur in 'n klein deeltjie van sy gewone dag:-Nog voor ontbyt kry hy in sy oggendkoerant sy daaglike dosis van -

(a) wat koerantverslaggewers dink hy behoort te weet van die politiek;

(b) wat die redakteur van hom verwag t.o.v. sake van die dag;

(c) wie vermoor of besteel of gevang of veroordeel is;

(d) wie verongeluk het, en

(e) wat in die loop van die dag van hom verwag sal word.

Nou ry hy na sy werk toe en van alle kante sak dit op hom toe in druk: Stop. Ry. Spoedlokvalle vorentoe. Ismael se kontantwinkel. Groot uitverkoping. Hotlikheid vermy padongelukke. Zie uit voor de trein. Ry met die rooi perd. Stop ens., ens. En dan neem ons hom kwalik wanneer hy reikhalsend uitsien na die verwesenliking van nog 'n advertensie wat hom aanraai: „Why go out? Stay at home!" Geleidelik dring dit tot die mens deur dat hy die slagoffer word van die gedrukte woord en dat hy deur die gedrukte woord die prooi word van hierdie eeu van die regulasie.

Met die drukkuns gaan dit seker maar soos met alle mooi en edele dinge in die lewe: hulle word misbruik wanneer hulle in die samelewing oor-georganiseer raak. Hier en daar kom daar nog die idealis wat vra: "Wat kan ek die wêreld bied deur my geskrifte?" Gewoonlik egter vra die skrywer maar net „Wat wil ek van die wêreld hê ?" en dit bepaal vir hom hoe hy sy gedagtes of gedagteloosheid moet inklee. Die volslae verslaafdheid van die moderne mens aan hierdie eeu van die regulasie ken ons hieraan: Hy kritiseer nie meer nie; hy argumenteer nie meer nie; hy vra nie meer of dit goed of sleg of sinneloos is nie. Hy vra bloot maar: „Wat kos dit?".

Ons kan enigsins 'n begrip kry van die ontsettende oorstimulering van die moderne mens wanneer ons 'n paar minute nadink oor die komplekse wêreld wat die kind van vandag in sy eerste $\mathbf{1 0}$ lewensjare moet bemeester in vergelyking met dié van sy voorgeslag van 100 jaar gelede. En een van die vernaamste prikkels wat voortdurend op die mens van vandag inwerk is die gedrukte woord.

Dit neem so 'n omvang aan dat hy nie eers kan begin om dit self te sif en te assimileer nie. Dit neem so 'n omvang aan dat die mens vir die behoud van sy geestelike balans genoodsaak is om daaraan te ontvlug. En een van die doeltreffendste ontvlugtingsmiddels is die groepinstink.

Die mens is vandag meer as ooit tevore lid van 'n groep; van 'n organisasie; van 'n vereniging. En binne hierdie groepsverband voel hy veiliger. Die groep skakel sommige van die menigvuldige prikkels vir die mens uit; die groep selekteer vir hom sekere prikkels en maak hom ontvanklik vir 'n bepaalde gedagterigting; die groep 
begeester hom en voer hom mee in 'n bepaalde stroom op daardie see waarin hy andersins rigtingsloos sou moes voortdobber; die groep kleur sy bril vir hom; die groep skep vir hom die geleentheid om homself daarbinne uit te lewe en om te presteer ten behoewe van die groep.

Maar hierdje groepsverband skep 'n nuwe dilemma van die moderne tyd. Moderne organisasie is onafskeidbaar verbonde aan spesialisasie; spesialisasie weer aan sentralisasie; en sentralisasie aan die haas ontvlugbare regulasie en daarin sit die individu opnuut weer magteloos verstrik. Elke groep het sy belange soos neergelê in sy beleid, sy kode en sy regulasies en dié kom onverbiddelik neer op „Wie nie vir ons is nie, is teen ons." Die groep duld t.o.v. sy begingels geen vrae en bedenkings nie, en hierdie beginsels is per slot van rekening die skeppinge van niemand anders as die groepsorganiseerders nie.

Laat ons nou vlugtig die Westerse gees teen hierdie agtergrond in oënskou neem, dan moet ons met drie stellinge rekening hou :

eerstens dat ware kultuurskepping en geestelike ontwikkeling ' $n$ hoogs individuele proses is;

tweedens dat ware kultuurskepping slegs kan ontstaan in ' $n$ atmosfeer van wrywing en verset en nooit agter die skerms of skanse van ontvlugting nie; en

derdens dat ware kultuurskepping ontstaan uit die wroeging van die paar begenadigdes wat vóór staan in die hitte van die stryd, maar op vaste fondamente van beginsel.
Staan ons dan nog verwonderd oor die geestelike bankrotskap van die Weste wanneer ons afhanklik is van die sogenaamde „Kultuurskeppinge" van organiseerders; wanneer die skeppende kunstenaars verstrik is in die beleidskole van hulle groep - hetsy dié van bekrompe konserwatisme of van baldadige bandeloosheid?

Dit is die duistere prentjie van die Westerse kultuur gesien vanuit die oogpunt van die massa. Daar is egter nog genoeg wat eerlik soek en wat eerlik skep. Daar is genoeg in die verlede wat 'n vaste fondament vir die toekoms bied. Daar is genoeg lewenskrag in die Westerse beskouing om hierdie stryd vir die behoud van die individualiteit vir baie eeue voort te sit en te voer tot die oorwinning. En daar is genoeg bewyse dat die owerhede van Westerse lande hierdie versmorende en verlammende uitwerking van die ontsettende massa drukwerk wil probeer verhoed. 'n Diepgaande studie van die aangeleentheid wat onlangs in ons land onderneem is het duidelik aangetoon dat die sogenaamde "onwenslike" literatuur indien nodig tog beheer kan word. Dit gaan veelmeer om die niksseggende drukwerk wat uit die aard van die saak geen vormende waarde het nie en wat geestelik en intellektuele ontwikkeling eerder strem as bevorder. In alle vrye lande van die wêreld, maar in ons eie land heel in die besonder, is dit belangrik om te waak teen die gevare van regimentering van gedagtes.

Terwyl ons dus moet sorg vir die afweer van 'n gedeelte van die oorweldigende stroom prul-lektuur moet ons terselfdertyd verseker dat die prikkeling 
van die kerngesonde en eerlike geskrifte vir ons nie verlore raak nie.

Die beoordeling van hierdie "kerngesondheid" en "eerlikheid" in enige geskrif is sekerlik een van die moeilikste probleme waarmee enige leser van enige geskrif te kampe het. Veral in die tyd waarin ons lewe hoor ons dikwels die klag dat die mense ,lui is om te dink", dat hulle "lui is om werke van beter gehalte te lees", en dat hulle „maar tevrede is om ontvlugting te soek van die harde lewensrealiteite deur die lees van niksseggende verdowingslektuur." Die saak is egter nie heeltemal so eenvoudig nie. My persoonlike waarneming van die leesgewoontes van die nagenoeg 135,000 lesers van die Transvaalse Provinsiale Biblioteekdiens bring duidelik aan die lig dat die mens van vandag soek na geestelike vastigheid; na intellektuele leiding en na iets waxraan hy kan glo. Die Westerse mens? het deur die eeue bekend geraak vir sy grootse denke; vir sy moed en lus om nuwe terreine te verower, en bowenal vir sy selfversekerde daadkrag. Nou wonder 'n mens of hy in die jongste wêreldbotsing so ' $n$ diep skok in sy wese ontvang het dat daardie kenmerkende selfversekerdheid totaal oorboord geval het. Boeke wat naamlik vandag indruk maak, is dié wat 'n vermoede moontlikheid met meesleurende geesdrif, met vuur en met oortuiging as die waarheid bevestig. As 'n skrywer aan hierdie vereistes beantwoord kan hy maar 'n uiters moeilike boek skrywe en tog nog verseker wees van 'n geweldige leserstal. As 'n skrywer aan hierdie vereistes voldoen kan hy selfs met halwe waarhede en verdraaide feite by die oorgrote meerderheid van sy lesers verbykom.

Die moderne mens wil volg; hy wil ingelig wees deur iemand wat klaarblyklik weet waarvan hy praat. In die moderne gekompliseerde wêreld het ons tog eenvoudig nie die tyd om alle meegedeelde feite te kontroleer nie. Ons is geneig om gedrukte stellings as waarheid te aanvaar, en gevolglik het die gedrukte leuen vandag veel verreikender gevolge as die gesproke waarheid. Die bemoedigende verskynsel is gelukkig dat die Westerse mens nog nie passief geword het nie. Hy soek nog. Hy sóek na rigting en vastigheid in sy omgang met sy medemens; maar hy soek veral na vastigheid deur middel van die gedrukte woord. Die feit dat die klein blanke bevolking van die Unic van Suid-Afrika in die loop van 1957 nie minder nie as $£ 6,000,000$ aan boeke bestee het, toon vir ons hoe naarstiglik daar in ons eie land deur ons eie mense gesoek word. Hierdie soeke bewys vir ons dat die onrus en lewenskrag van die Westerse gees tog nog behoue gebly het. Hierdie soeke bied vir ons sterker en groter hoop vir die toekoms. Hierdie soeke bepaal die lewenstaak vir die noodsaaklike bondgenootskap van skrywer, uitgewer, boekhandelaar en bibliotekaris.

En juis in die leiding en bevrediging van hierdie soeke lê vir my die beskeie maar tog gewigtige taak van die moderne bibliotekaris. Beskeie is dit beslis want die bibliotekaris behoort uit die aard van die saak nie tot die begenadigde groep wat die skeppende arbeid verrig nie. Gewigtig is dit egter tog wel want die bibliotekaris is daarvoor 
verantwoordelik om die lewendige wisselwerking tot stand te bring tussen die gedrukte woord en die menslike gees.

In sy verhouding tot die wêreldpers is dit die taak van die bibliotekaris om ontvanklik maar streng nugter en objektief te staan vir die versameling en ordening en disseminasie van daardie menslike gedagtes wat sy geslag en die nageslagte kan prikkel in hulle nimmereindigende soektog na die waarheid. In hierdie hoedanigheid is hy ' $n$ liefdevolle dienaar van die geskrewe woord, want iedere stuk in sy versameling word vir hom 'n skynende lig: soms die vrolike lig van ontspanning; soms die sagte lig van mymering en vergeestelikende bepeinsing; soms die helder lig van die geïnspireerde skoonheid; soms die skerp lig van die nuut-ontdekte waarheid; soms die lonkende lig van die onbekende; maar dikwels ook die brandende lig op die seer plekke wat genees of uitgesny moet word. Die bibliotekaris moet lei maar mag nooit indoktrineer nie. Sy versameling moet so opgebou word dat dit die volle lig van die tyd vir sy leser oor die onderwerp laat opgaan, maar hy mag daardie lig nie met sy eie vooroordele kleur nie.

In sy verhouding teenoor sy medemens moet die bibliotekaris in die eerste plek onthou dat die biblioteek nooit mag ontaard in nog 'n ontvlugting van die moderne tyd nie. Omdat hy oortuig is van die intrinsieke waarde van sy versameling sal die bibliotekaris die inhoud daarvan uitdra na die groots moontlike deel van die gemeenskap wat hy moet bedien. Hy mag egter nie valse beloftes doen of sy lesers in die basiese gehalte van sy versameling teleurstel nie. Omdat hy weet dat die moderne mens op sy beste deur middel van sy groepsverband bereik kan word, sal die bibliotekaris van die groepsverband gebruikmaak om die individu tot denke en die soek na waarheid te prikkel. Hiervoor sal hy diens aan die groep lewer en die groep geen skade berokken nie, maar hy sal altyd onthou dat ware biblioteekdiens slegs diens aan die enkeling kan beteken. Die bibliotekaris as dienaar van die gemeenskap sal probeer om nooit die kosbare tyd van sy lesers met prulwerk te mors nie, maar hy sal sorg dat hy nooit sy lesers sal verhinder om tot diepere insigte en waarhede te kom nie selfs al sou daardie waarhede langs eensame en pynlike weë lei. Ook sal hy nooit sy persoonlike opvattinge of oortuigings of vooroordele of gevolgtrekkinge aan sy lesers opdring nie. Hy sal egter sorg dat al die beste inligting beskikbaar gestel word en dit dan aan sy lesers oorlaat om elkeen sy eie gevolgtrekkinge te maak. Die bibliotekaris aanvaar dit as sy roeping om die biblioteek op te bou tot die intellektuele brandpunt van sy gemeenskap - ook van die enkele begenadigde begaafdes in sy gemeenskap - en hy besef dat hy aan hierdie vereiste slegs deur die grootste persoonlike toewyding aan sy taak kan voldoen. Die bibliotekaris sal die individualiteit van elke lid van sy gemeenskap met die grootste agting bejeën, maar sal probeer om die geestelike en intellektuele isolasie van iedere lid van sy gemeenskap te verhoed. Omdat die bibliotekaris dit as sy roeping beskou om die lewende skakel te vorm tussen die mens en die gedrukte woord sal hy met die moed van sy oortuiging 
sorg dat daar wisselwerking plaasvind; dat daar krities gelees word en dat sy inrigting nie ontaard in ' $n$ wit olifant waarin alleen die boekwurms ooit die voorreg het om die binnekant van sy boeke te sien te kry - en dit in die donker.

En nou is daar ' $n$ paar gedagtes wat van besondere toepassing is op die Afrikanerbibliotekaris: $\mathrm{Hy}$ glo aan die vryheid van die individu; hy glo an die voortbestaan van die Christelike Westerse beskawing ten spyte van die diep waters waardeur ons moet gaan; hy glo aan die toekoms van ons land en aan die taak van die Westerse beskawing hier aan die suidpunt van Afrika. Hy glo veral dat hierdie Westerse beskawing gegrondves staan op ewige, onomstootlike waarhede. In sy strewe na die wese van die waarheid het die Westerse gees menigvuldige paaie bewandel en reeds menigvuldige aspekte van hierdie waarhede belig. En nou lê die taak van die Afrikanerbibliotekaris daarin om die soeker van vandag te help tot kennis, tot waardering, en tot verklaring van daardie waarhede in die taal van die tyd.

Die Jobstroosters onder $\mathbf{u}$ mag voel dat my geloof in die hede en my moed vir die toekoms misplaas is. $U$ mag aanvoer dat die soek na waarheid in die verwarrende, gekompliseerde en oorweldigende moderne tyd gelykstaan aan die tradisionele soektog na 'n naald in 'n hooimied. Miskien is $u$ reg. Ek wil egter vir $u$ hierdie feit noem.

Gestel dat die ergste gebeur en dat die hele kafmied afbrand. Dan kan ek nog aan $u$ sê ek weet dat die hitte van brandende kaf nie warm genoeg is om die getemperde staal van 'n naald te laat smelt en in die niet te laat verdwyn nie.

Toespraak deur F. M. Robinson by geleentheid van die Diplomadag van die P.U. vir C.H.O. op Vrydag 28 November 1958 